\title{
Magmatic evolution of a Neoarchean greenstone belt
}

\author{
LUCIE MATHIEU ${ }^{1}$, BAPTISTE MAdON ${ }^{1}$, ALEXANDRE \\ CRÉPON $^{1}$, PATRICK BERTHOTY ${ }^{1}$, DANIEL KONTAK ${ }^{2}$ \\ ${ }^{1}$ Université du Québec à Chicoutimi (UQAC), Chicoutimi, \\ Québec, Canada - lucie1.mathieu@uqac.ca
}

${ }^{2}$ Laurentian University, Sudbury, Ontario, Canada

In Archean greenstone belts, magmatism of the synvolcanic period is dominated by tholeiites, as well as tonalite- and granodiorite-dominated large-volume batholiths, i.e., tonalite-trondhjemite-granodiorite (TTG) suites. During the syntectonic period (main deformation phase that lead to craton stabilization), small-volume intrusions with alkaline affinities, as well as sanukitoids and biotite granite plutons, dominate. Synvolcanic intrusions are associated with poorly documented mineralization ( $\mathrm{Cu}-\mathrm{Au}$ porphyries) that, in the Neoarchean Abitibi Subprovince $(>2.79$ to $\sim 2.65 \mathrm{Ga})$, Superior Province, Canada, are associated with diorite bearing plutons, i.e., tonalite-trondhjemite-diorite (TTD) suites. Syntectonic intrusions, in turn, could be genetically related to intrusion-related gold systems (IRGS). The importance of TTG versus TTD suites in the evolution of greenstone belts, the late onset of K-bearing magmatism and the importance of related mineralization is unconstrained. This contribution presents preliminary results that portray the chemistry and distribution of tonalite-dominated magmatism in the Abitibi Subprovince, and provides insights into physico-chemical parameters such as pressure, temperature, and oxygen fugacity $\left(f \mathrm{O}_{2}\right)$. The study used data compiled by the geological surveys of Québec and Ontario to evaluate the chemistry of TTG and TTD suites and uncovered two coeval magmas that significantly differentiated (fractional crystallization mostly): 1) a HREE-depleted tonalitic magma from high pressure melting of a hydrated basalt source (TTG suite); and 2) a hybrid HREE-undepleted magma that may be a mixture of mantle-derived (tholeiite) and tonalitic melts (TTD suite). Apatite and zircon chemistry show a marked increase of the $\mathrm{fO}_{2}$ parameter during the syntectonic period. Tonalite-dominated magmatism of the synvolcanic period, in the Abitibi Subprovince, comprises crustal melts as well as a significant proportion of mantle-derived magma (i.e., diorite) which may be essential for $\mathrm{Cu}-\mathrm{Au}$ magmatic-hydrothermal mineralizing system. The increase in magmatic $f \mathrm{O}_{2}$ and $\mathrm{K}$ content during the styntectonic period may indicate a metasomatised mantle source that may be paramount to the IRGS metallogenic model. 